\title{
AKTIVITAS ANTIINFLAMASI EKSTRAK KAYU BAJAKAH (SPATHOLOBUS LITTORALIS HASK)
}

\section{Anti-inflammatory Activity of Bajakah Wood Extract (Spatholobus Littoralis Hask)}

\section{Kunti Nastati ${ }^{\text {* }}$ \\ Dyan Fitri Nugraha '}

IPharmacy Department, Health Faculty, Sari Mulia University, Banjarmasin City, South Borneo 70238, Indonesia

*email:

kuntinastiti@unism.ac.id

Kata Kunci:

Kayu Bajakah (Spatholobus

Littoralis Hassk)

Antiinflamasi

Keywords:

Bajakah Wood (Spatholobus

Littoralis Hassk)

Antiinflamasi

\begin{abstract}
Abstrak
Kayu Bajakah (Spatholobus Littoralis Hassk) merupakan tanaman asli Kalimantan yang banyak digunakan oleh masyarakat untuk menyembuhkan diare, obat disentri, obat pegal linu, obat luka bahkan dipercaya sebagai obat kanker. Penelitian mengenai tanaman ini masih sangat terbatas. Kandungan flavonoid diduga yang berperan sebagai antiinflamasi. Tujuan penelitian ini untuk mengetahui efektivitas Kayu Bajakah (Spatholobus Littoralis Hassk) sebagai antiinflamasi pada tikus jantan yang diinduksi karagenin. Metode yang digunakan dalam penelitian ini adalah metode eksperimental yang menggunakan 2I ekor tikus tikus putih jantan umur 2-3 bulan dengan berat 150-250 gram yang dibagi menjadi 7 kelompok, yaitu kelompok normal, kelompok CMC Na, kelompok Natrium diklofenak I,35 mg/200gBB dan 4 tingkatan dosis ekstrak etanol Kayu Bajakah : 50, 100, 200 dan 400 mg/KgBB per oral. Lima belas menit setelah perlakuan tikus diinjekasi dengan karagenin $1 \%$ secara subplantar. Volume udem diukur dengan alat plestimometer setiap 60 menit selama 4 jam. Daya antiinflamasi diukur dengan dengan membandingkan nilai persentase hambatan udem kelompok kontrol dan perlakuan. Hasil penelitian menunjukkan keempat kelompok perlakuan memiliki total volume udem yang berbeda bermakna pada menit ke 240' dengan nilai signifikansi lebih kecil dari 0,05. Daya antiiflamasi terbesar pada dosis $400 \mathrm{mg} / \mathrm{KgBB}$ pada menit ke 240 dengan persentase sebesar 87,65\%. Ekstrak etanol Kayu Bajakah (Spatholobus Littoralis Hassk) memiliki aktivitas sebagai antiinflamasi.
\end{abstract}

\begin{abstract}
Bajakah wood (Spatholobus Littoralis Hassk) is a native plant of Kalimantan which is widely used by the community to treat diarrhea, dysentery, aches and pains, wound medicine and is even believed to be a cancer drug. Research on this plant is still very limited. The content of flavonoids is thought to act as an antiinflammatory. The purpose of this study was to determine the effectiveness of Kayu Bajakah (Spatholobus Littoralis Hassk) as an anti-inflammatory in male rats induced by carrageenin. The method used in this study was an experimental method using 21 male white rats aged 2-3 months weighing I50-250 grams which were divided into 7 groups, namely the normal group, the CMC Na group, the diclofenac sodium group $1.35 \mathrm{mg} /$ day. 200gBW and 4 doses of Kayu Bajakah ethanol extract: $50,100,200$ and $400 \mathrm{mg} / \mathrm{KgBW}$ orally. Fifteen minutes after treatment, mice were injected with $1 \%$ carrageenin subplantar. The volume of edema was measured with a plestimometer every 60 minutes for 4 hours. Antiinflammatory was measured by comparing the percentage value of edema inhibition in the control and treatment groups. The results showed that the four treatment groups had a significantly different total volume of edema at 240' minute with a significance value less than 0.05 . The greatest anti-inflammatory effect was at a dose of $400 \mathrm{mg} / \mathrm{KgBW}$ at the 240th minute with a percentage of 87.65\%. Kayu Bajakah (Spatholobus Littoralis Hassk) ethanol extract has antiinflammatory activity.
\end{abstract}

(C) year The Authors. Published by Institute for Research and Community Services Universitas Muhammadiyah Palangkaraya. This is Open Access article under the CC-BY-SA License (http://creativecommons.org/licenses/by-sa/4.0/) DOI: https://doi.org//0.33084/jsm.vxix.xxx.

\section{PENDAHULUAN}

Kayu Bajakah (Spatholobus Littoralis Hassk) merupakan tumbuhan asli Kalimantan yang dapat ditemui di hutan di pedalaman Kalimantan. Tumbuhan ini berbentuk batang bersulur dan merambat yang tumbuh, diketahui banyak tumbuh di hutan Kalimantan Tengah dengan jumlah yang terbatas. Kayu Bajakah (Spatholobus Littoralis Hassk) telah dikenal masyarakat Kalimantan sebagai tumbuhan berkhasiat obat dan dikenal dengan 
sebutan kayu bajakah tampala. Secara empiris tanaman ini digunakan oleh masyarakat dayak secara turun temurun sebagai pengobatan berbagai macam penyakit. Air rebusan dari kayu bajakah mampu dimanfaatkan untuk menyembuhkan diare, obat disentri, obat pegal linu, obat luka, dll. Bahkan dipercaya sebagai penyembuh kanker. Kayu bajakah (Spatholobus Littoralis Hassk) juga dimanfaatkan dalam bentuk handsanitizer karena kandungan senyawanya terbukti memiliki aktivitas antibakteri E. Coli (Noval et al., 2020); (Saputera et al., 2020).

Penelitian tentang tanaman Kayu Bajakah (Spatholobus Littoralis Hassk) saat ini masih terbatas pada uji kandungan kimia dan efektivitas terhadap bakteri $E$. Coli. Kandungan kimia tanaman Kayu bajakah antara lain flavonoid, alkaloid dan steroid (Iskandar \& Warsidah, 2020). Senyawa aktif yang banyak berperan terhadap efek farmakologis suatu tumbuhan obat adalah golongan flavonoid. Senyawa flavonoid mempunyai potensi sebagai penyembuh luka dan sebagai antiradang (Panche et al., 2016). Senyawa ini mampu menghambat ekspresi isoform sintase oksida nitrat, siklooksigenase, dan lipooksigenase, yang bertanggung jawab keluarnya mediator inflamasi seperti histamin, bradikinin, serotonin, leukotrien, dan prostaglandin (Corwin, 2009). Senyawa flavonoid juga berkhasiat sebagai antioksidan yang dapat mempercepat penyembuhan luka maupun inflamasi (Ginwala et al., 2019). Ekstrak etanol kayu bajakah mempunyai daya antioksidan sangat kuat yaitu $I_{50}$ sebesar 8,25 $\mu \mathrm{g} / \mathrm{ml}$ (Iskandar \& Warsidah, 2020).

Peradangan atau inflamasi merupakan suatu upaya pertahanan tubuh sebagai respon terhadap cedera ataupun ganguan suatu penyakit akibat infeksi (Noval et al., 2017). Inflamasi dapat diobati dengan obat antiinflamasi golongan steroid (AIS) dan golongan obat nonsteroid (AINS) (Katzung et al., 2014). Obat antiinflamasi sintetik mempunyai efek yang cepat dalam memulihkan peradangan namun mempunyai efek samping iritasi lambung jika digunakan jangka panjang. Sehingga diupayakan adanya obat tradisional yang mempunyai efektivitas sebagai antiinflamasi karena obat tradisional dinilai memiliki efek samping yang lebih ringan dibandingkan obat sintetik (Noval et al., 202I).

Penelitian pengujian efektivitas secara farmakologis tanaman Kayu Bajakah masih belum banyak dilakukan. Penelitian ini bertujuan untuk mengetahui apakah tanaman Kayu Bajakah (Spatholobus Littoralis Hassk) ini dapat berfungsi sebagai antiinflamasi atau antiradang. Pada umumnya masyarakat sudah banyak menggunakan tanaman untuk mengobati berbagai macam penyakit yang berhubungan dengan peradangan salah satunya sebagai penyembuh luka (Kurniawati, et al., 2020), namun penggunaan tanaman obat tersebut masih belum banyak didukung oleh data penelitian secara ilmiah (Nastiti, et al., 202I).

Berdasarkan latar belakang di atas, tujuan yang akan diteliti adalah untuk mengetahui potensi tanaman Kayu Bajakah (Spatholobus Littoralis Hassk) sebagai antiinflamasi.

\section{METODOLOGI}

Alat yang digunakan dalam penelitian ini adalah alatalat gelas @Pyrex Iwaki Glass, batang pengaduk, blender, plestimometer air raksa (manual), spuit injeksi@OneMed, sonde, timbangan BB @SF-400, rotary evaporator @Re-I00 pro, botol kaca, maserator, oven@Memmert, pinset, pipa kapiler, pipet tetes, pipet ukur, propipet ${ }^{@} \mathrm{D} \& \mathrm{~N}$, rak tabung, semprotan, spatel, timbangan analitik @Ohauss, waterbath @Memmert.

Bahan yang digunakan dalam penelitian ini kayu bajakah, akuades, CMC Na, Karagenin, Natrium diklofenak @Sanbe, etanol p.a @Merck, etanol 96\%, kalium asetat I M, kertas saring Whatman.

\section{Jalannya Penelitian}


I. Preparasi Ekstrak Kayu Bajakah (Spatholobus Littoralis Hassk)

Simplisia sebanyak 500g Kayu Bajakah (Spatholobus Littoralis Hassk) diserbuk dan diayak dengan ayakan no mesh 40 . Selanjutnya serbuk diekstraksi dengan metode maserasi menggunakan etanol $96 \%$ selama $3 \times 24$ jam dan remaserasi berulang hingga bening. Setiap harinya sesekali dilakukan pengadukan. Hasil rendaman kemudian disaring dan dipekatkan menggunakan rotary evaporator pada suhu $50^{\circ} \mathrm{C}$ hingga diperoleh ekstrak kental. Selanjutnya dilakukan perhitungan rendemen.

2. Pembuatan suspensi natrium diklofenak dan karagenin

Natrium diklofenak $75 \mathrm{mg}$ dan karagenin I\% disuspensikan ke dalam CMC 0,5\%.

3. Pengujian antiinflamasi kayu bajakah (Spatholobus Littoralis Hassk)

Penelitian ini menggunakan 21 ekor tikus jantan Galur Wistar berumur 3-4 bulan dengan berat badan 150-250g. semua kelompok diadaptasi selama seminggu di lingkungan laboratorium dan diberi makan ad libitum. Sebelum pengujian tikus dipuasakan selama kurang lebih 16 jam dan tetap diberikan air minum. Uji aktivitas antiinflamasi menggunakan metode induksi karagenin $1 \%$ diberikan secara subplantar pada telapak kaki tikus (Fridiana, 2012).

Pada saat pengujian tikus ditimbang berat badannya dan ditandai pada bagian mata kaki kirinya. Setiap tikus dari masing-masing kelompok diukur volume normal kaki kiri belakangnya dengan dicelupkan ke dalam cairan raksa pada alat plestimometer (Noval \& Raihana, 2019). Hewan uji masing-masing kelompok (Tabel I) kecuali kelompok normal, diberi perlakuan secara per oral. Setelah 15 menit pemberian oral, semua hewan uji kecuali kelompok normal diinjeksikan dengan karagenin I\% secara subplantar pada telapak kaki kiri. Pengukuran aktivitas antiinflamasi diukur dengan alat plestimometer mulai dari menit ke 0 (sebelum pemberian karagenin 1\%), 60, 120, 180 dan 240 menit setelah terinduksi karagenin I\% (Fridiana, 20I2). Analisis data menggunakan one way ANOVA.

Tabel I. Pelakuan dalam Setiap Kelompok Hewan Uji

\begin{tabular}{|c|c|}
\hline Nama & Perlakuan \\
\hline $\begin{array}{l}\text { Kelompok I (kontrol } \\
\text { normal) }\end{array}$ & Hewan uji tidak diberikan perlakuan \\
\hline $\begin{array}{l}\text { Kelompok II (kontrol } \\
\text { negative) }\end{array}$ & $\begin{array}{l}\text { Hewan uji hanya diberikan CMC Na } \\
0,5 \%\end{array}$ \\
\hline $\begin{array}{l}\text { Kelompok III (kontrol } \\
\text { Positif) }\end{array}$ & $\begin{array}{l}\text { Hewan uji diberikan suspensi Natrium } \\
\text { diklofenak I,35 mg/200gBB dalam } \\
\text { pelarut } \mathrm{CMC} \mathrm{Na} \mathrm{0,5 \%}\end{array}$ \\
\hline Kelompok IV & $\begin{array}{l}\text { Hewan uji diberikan suspense ekstrak } \\
\text { Kayu Bajakah dosis } 50 \mathrm{mg} / \mathrm{KgBB} \text { dalam } \\
\text { pelarut } \mathrm{CMC} \mathrm{Na} 0,5 \%\end{array}$ \\
\hline Kelompok V & $\begin{array}{l}\text { Hewan uji diberikan suspense ekstrak } \\
\text { Kayu Bajakah dosis } 100 \mathrm{mg} / \mathrm{KgBB} \\
\text { dalam pelarut CMC Na } 0,5 \%\end{array}$ \\
\hline Kelompok VI & $\begin{array}{l}\text { Hewan uji diberikan suspense ekstrak } \\
\text { Kayu Bajakah dosis } 200 \mathrm{mg} / \mathrm{KgBB} \\
\text { dalam pelarut CMC Na } 0,5 \%\end{array}$ \\
\hline Kelompok VII & $\begin{array}{l}\text { Hewan uji diberikan suspense ekstrak } \\
\text { Kayu Bajakah dosis } 400 \mathrm{mg} / \mathrm{KgBB} \\
\text { dalam pelarut CMC Na } 0,5 \%\end{array}$ \\
\hline
\end{tabular}

\section{HASIL DAN PEMBAHASAN}

Kayu Bajakah didapatkan di daerah Rungan Barat, Kabupaten Gunung Mas, Kalimantan Tengah. Satu kilogram kayu Bajakah diserut menggunakan alat serutan kayu, kemudian dikeringkan dibawah sinar matahari tidak secara langsung dengan ditutup kain hitam selama 3 hari. Kemudian dilanjutkan dikeringkan menggunakan oven dengan suhu $50 \mathrm{C}$ selama 2 hari. Didapatkan 432,39 gram kemudian diekstraksi dengan metode maserasi dengan pelarut etanol $96 \%$ selama $3 x$ 24 jam dilanjutkan remaserasi sebanyak 2 kali. Hasil maserasi kemudian disaring sehingga didapatkan filtrat dan selanjutkan diuapkan dengan rotary evaporator hingga didapatkan ekstrak kental sebanyak 10,28 g. Rendemen ektrak yang didapatkan sebesar 2,38\%.

Ekstraksi Kayu Bajakah menggunakan etanol $96 \%$ dengan persentase rendemen ekstrak yang diperoleh sebesar 2,38\%. Ekstrak kemudian diujikan efektivitas sebagai antiinflamasi dengan metode induksi kimia dengan menggunakan karagenin $1 \%$. 
Tabel 3. Rata-rata persentase edema pada kaki tikus

\begin{tabular}{|c|c|c|c|c|c|c|}
\hline \multicolumn{7}{|l|}{ Waktu } \\
\hline & \multirow{2}{*}{$\begin{array}{l}\mathrm{CMC} \\
\mathrm{Na}\end{array}$} & \multirow[t]{2}{*}{ Obat } & \multicolumn{4}{|c|}{ Ekstrak Kayu Bajakah (mg/KgBB) } \\
\hline & & & 50 & 100 & 200 & 400 \\
\hline \multirow[t]{2}{*}{60} & $77,78 \pm$ & 27,78 & $67,78 \pm$ & 65,56 & 33,11 & 30,55 \\
\hline & 19,24 & $\pm 4,81$ & 1,92 & $\pm 1,92$ & $\pm 0,38$ & $\pm 4,81$ \\
\hline \multirow[t]{2}{*}{120} & $99,44 \pm$ & $8,33 \pm$ & $66,6 \pm 0$ & 63,33 & 32,78 & 38,89 \\
\hline & 0,96 & 14,43 &, 19 & $\pm 3,33$ & $\pm 0,96$ & $\pm 9,62$ \\
\hline \multirow[t]{2}{*}{180} & $99,67 \pm$ & 19,44 & $70 \pm 3,3$ & 35,56 & 32,22 & 23,53 \\
\hline & 0.58 & $\begin{array}{c} \pm 17,3 \\
4\end{array}$ & 3 & $\pm 38,5$ & $\pm 1,92$ & $\pm|2|$, \\
\hline \multirow[t]{2}{*}{240} & $99,89 \pm$ & 27,06 & $98,6 \pm 1$ & 34,33 & $22,2 \pm$ & 10,75 \\
\hline & 0,19 & \pm 5.86 & ,7I & $\pm 2,03$ & $|0,7|$ & $\pm 14,3$ \\
\hline
\end{tabular}

Ekstrak kayu bajakah terhadap aktivitas antiinflamasi diujikan secara in vivo dengan hewan uji tikus. Hasil pengukuran edema disajikan dalam tabel, kemudian dihitung perubahan volume edema setiap waktu pengamatan dan dihitung persentase edema setiap kelompok perlakuan pada setiap waktu pengamatan. Nilai rata-rata perubahan presentasi edema untuk setiap kelompok disajikan pada Tabel 3 dan Grafik I.

Tabel 3. menunjukkan bahwa pada kelompok kontrol negatif (CMC Na) terjadi peningkatan persentase edema. Sedangkan kelompok kontrol positif (obat natrium diklofenak) terjadi penurunan presentase maksimal pada menit ke 240'.

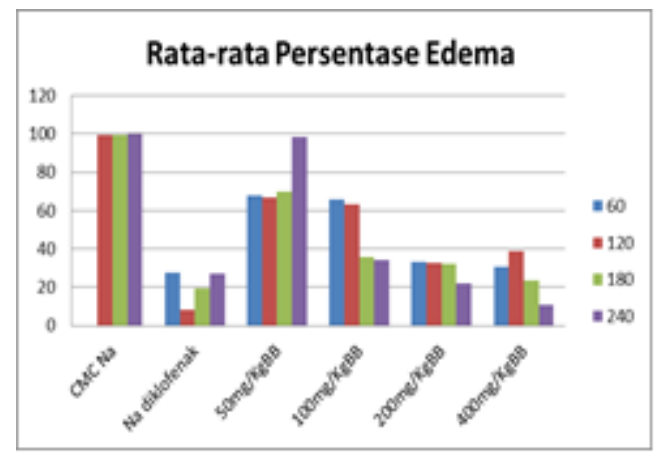

Grafik I. Diagram batang persentase edema ratarata kaki tikus pada setiap pengamatan.

Pada kelompok ekstrak dosis $50 \mathrm{mg} / \mathrm{KgBB}$ penurunan edema tidak begitu terlihat namun mulai dosis 100 $\mathrm{mg} / \mathrm{KgBB}$ terjadi penurunan persentase edema mulai pada menit ke 240'.
Persentase hambatan edema kaki tikus paling besar terjadi pada dosis $400 \mathrm{mg} / \mathrm{KgBB}$ yang puncaknya terjadi pada menit ke 240'. Ilustrasi juga dapat terlihat pada diagram batang pada Grafik 2. Selanjutnya, dari presentase edema rata-rata kaki tikus pada setiap pengamatan dapat dihitung persentase hambatan edema. Persentase hambatan edema pada kaki tikus dapat dilihat pada Tabel 4.

Tabel 4. Rata-rata persentase hambatan pada kaki tikus

\begin{tabular}{lcrrrrr}
\hline Waktu & Perlakuan & & \multicolumn{5}{c}{ Ekstrak Kayu Bajakah (mg/KgBB) } \\
& CMC Na & Obat & & & & \\
\cline { 4 - 7 } & & & 50 & 100 & 200 & 400 \\
\hline 60 & - & 64,28 & 12,86 & 15,71 & 57,43 & 60,71 \\
120 & - & 91,62 & 33,37 & 36,31 & 67,04 & 60,89 \\
180 & - & 80,49 & 29,61 & 64,33 & 67,67 & 79,73 \\
240 & - & 72,91 & 1,11 & 65,62 & 77,75 & 87,65 \\
\hline
\end{tabular}

Tabel 4. menunjukkan bahwa kelompok natrium diklofenak (positif) mampu menghambat edema terbesar pada menit ke 120' sebesar 91,62\% dan pada menit ke 240' kemampuan menghambat edema semakin menurun. Pada kelompok ekstrak 50 $\mathrm{mg} / \mathrm{KgBB}$ kemampuan hambatan udema terdapat pada menit ke 240' sebesar 33,37\%. Pada kelompok ekstrak $100 \mathrm{mg} / \mathrm{KgBB}$ mempunyai kemampuan hambatan edema pada menit ke 240' sebesar 65,62\%. Pada kelompok ekstrak $200 \mathrm{mg} / \mathrm{Kg}$ BB hambatan udema terjadi pada menit ke 240 sebesar 77,75\%. Pada ekstrak 400mg/KgBB mempunyai hambatan edema terbesar dibanding kelompok ekstrak lainnya yang terjadi pada menit ke 240 ' sebesar $87,65 \%$. Ilustrasi tersebut juga dapat terlihat diagram batang pada Grafik 2. 


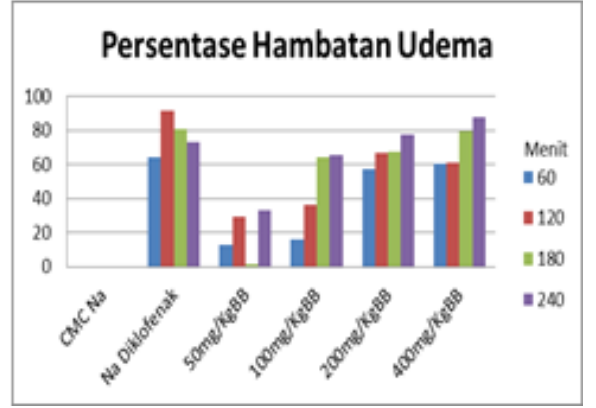

Grafik 2. Diagram Batang Persentase Hambatan Udema (\%)

Data rata-rata persentase edema pada setiap waktu pengamatan tersebut selanjutnya diuji menggunakan uji Kolmogorov-smirnov untuk mengetahui sebaran data. Hasil menunjukkan data perubahan persentase edema pada setiap kelompok perlakuan terdistribusi normal dengan signifikansi sebesar $>0,05$. Selanjutnya data tersebut diuji menggunakan uji Levene untuk mengetahui homogenitas data. Hasil Uji Levene menunjukkan data normal dengan nilai signifikansi sebesar >0.05. Berdasarkan uji normalitas dan homogenitas data hasil penelitian memiliki nilai yang normal dan homogen sehingga dapat dilakukan dengan Uji One-way Anova.

Data persentase edema diuji dengan One-way Anova untuk mengetahui ada tidaknya perbedaan pada kelompok perlakuan. Hasil One-way Anova menunjukkan nilai signifikansi sebesar $<0.05 \quad(p<0,05)$ yang artinya terdapat perbedaan perubahan persentase edema yang bermakna setiap waktu pengamatan. Data tersebut perlu dilakukan untuk uji lanjutan dengan Tukey HSD dan Uji LSD untuk mengetahui kelompok mana yang berbeda makna dengan kelompok lain. Pada uji ini, data dianggap memiliki perbedaan yang signifikan apabila memiliki nilai signifikansi kurang dari 0,05. Hasil data menunjukkan adanya perbedaan bermakna antara kontrol postif (Natrium diklofenak) dan negatif (CMC-Na). Pada menit ke 60 tidak ada perbedaan bermakna antara kontrol negatif dengan kelompok dosis $50 \mathrm{mg} / \mathrm{KgBB}$ dan $100 \mathrm{mg} / \mathrm{KgBB}$. Pada menit ke 120' Terjadi perbedaan bermakna antara kontrol negatif dengan semua kelompok perlakuan namun tidak berbeda bermakna anara kelompok dosis 50 $\mathrm{mg} / \mathrm{KgBB}$ dengan $100 \mathrm{mg} / / \mathrm{KgBB}$. Pada menit ke 180 , terdapat perbedaan bermakna antara kelompok negatif dengan semua kelompok perlakuan kecuali $50 \mathrm{mg} / \mathrm{KgBB}$, sedangkan antara kelompok dosis terjadi perbedaan bermakna. Pada menit ke 240 terjadi perbedaan bermakna antara tiap perlakuan dosis ekstrak Kayu Bajakah.

Kandungan Kayu Bajakah (Spatholobus Littoralis Hassk) meliputi alkaloid, flavonoid dan steroid ((Iskandar \& Warsidah, 2020). Adanya kemampuan menurunkan persentase edema diduga terjadi karena aktifitas senyawa aktif tersebut. Senyawa Flavonoid memiliki kemampuan memblok siklooksigenase dan lipooksigenase asam arakidonat sehingga sintesis mediator inflamasi (PGE2, leukotrien, histamin, bradikinin dan tromboksan) menjadi terhambat sehingga dapat mengurangi edema dan juga menghambat sitokin yang memodulasi rasa nyeri (Verri et al., 2012). Selain senyawa flavonoid, senyawa lain seperti senyawa alkaloid mampu menghambat terlepasnya prostaglandin pada jaringan yang meradang sehingga memberikan kontribusi terhadap penurunan terjadinya inflamasi (Barbosa Filho et al., 2006). Senyawa steroid pada tanaman mempunyai struktur kimia yang ideal sebagai antiinflamasi (Patel et al., 20I5).

\section{KESIMPULAN}

Ekstrak Kayu Bajakah mempunyai efektivitas sebagai antiinflamasi.

\section{UCAPAN TERIMA KASIH}

Kami ucapkan terimakasih kepada Kementerian Riset dan Teknologi/Badan Riset dan Inovasi Nasional yang telah mendanai hibah penelitian ini.

\section{REFERENSI}


I. Noval, N., Nastiti, K., Nugraha, D. F., Rahmadani, R., \& Alawiyah, T. (2020). PRODUK INOVASI HAND SANITIZER DARI AKAR BAJAKAH SEBAGAI UPAYA PENCEGAHAN DI MASA PANDEMI COVID-19. LOGISTA - Jurnal Ilmiah Pengabdian Kepada Masyarakat; Vol 4 No 2 (2020). https://doi.org//0.25077/logista.4.2.305-312.2020

2. Saputera, M. M. A., Marpaung, T. W. A., \& Ayuchecaria, N. (2020). KONSENTRASI HAMBAT MINIMUM (KHM) KADAR EKSTRAK ETANOL BATANG BAJAKAH TAMPALA (Spatholobus littoralis Hassk) TERHADAP BAKTERI ESCHERICHIA COLI MELALUI METODE SUMURAN. Jurnal Ilmiah Manuntung; Vol 5 No 2 (20/9): Jurnal Ilmiah Manuntung. https://doi.org/10.51352/jim.v5i2.267

3. Iskandar, D., \& Warsidah, W. (2020). Qualitative Phytochemical Screening and Antioxidant Activity of Ethanol Root Extract of Spatholobus littoralis Hassk. The Journal of Food and Medicinal Plants, I(I), I3-I5. https://doi.org//0.25077/jfmp.I.I.I3$\underline{15.2020}$

4. Panche, A. N., Diwan, A. D., \& Chandra, S. R. (2016). Flavonoids: an overview. Journal of Nutritional Science, 5, e47-e47. https://doi.org/10.1017/jns.2016.4I

5. Corwin, E. J. (2009). Buku Saku Patofosiologi (3rd ed.). EGC.

6. Ginwala, R., Bhavsar, R., Chigbu, D. I., Jain, P., \& Khan, Z. K. (2019). Potential Role of Flavonoids in Treating Chronic Inflammatory Diseases with a Special Focus on the Anti-Inflammatory Activity of Apigenin. Antioxidants (Basel, Switzerland), 8(2), 35. https://doi.org/10.3390/antiox8020035

7. Noval, N., Hakim, A. R., \& Irawan, A. (20I7, December). Antipyretic Effects of (phaleria macrocarpa (scheff) boerl.) Infusa In Mice Galur Wistar As Animal Model. In 2nd Sari Mulia International Conference on Health and Sciences 2017 (SMICHS 2017)-One Health to Address the Problem of Tropical Infectious Diseases in Indonesia (pp. 359-368). Atlantis Press.

8. Katzung, B. G., Masters, S. B., \& Trevor, A. J. (20I4). Farmakologi dasar dan Klinik Vol. I, Edisi $I 2$. Penerbit Buku Kedokteran EGC, Jakarta.

9. Noval, N., Nugraha, D. F., Nastiti, K., Syahrina, D., \& Novia, N. (202I). Local Natural Product Development in the Era of Covid 19 Pandemic. Indonesia Berdaya, 2(2), I33-I40.
10. Kurniawati, D., Noval, N., \& Nastiti, K. (2020). Potensi antiseptik poliherbal daun sirih (piper betle), kulit jeruk nipis (citrus aurantifolia) dan tanaman bundung (actinuscirpus grossus) pada tindakan keperawatan dan kebidanan. DINAMIKA KESEHATAN: IURNAL KEBIDANAN DAN KEPERAWATAN, I I (I), 420-43I.

I I. Nastiti, K., Noval, N., \& Kurniawati, D. (202I). Uji Aktivitas Antioksidan Kombinasi Infusa Daun Sirih (Piper betle L), Ekstrak Etanolik Tanaman Bundung (Actinuscirpus grossus) dan Kulit leruk Nipis (Citrus aurantifolia). Jurnal Surya Medika (JSM), 7(I), II5-I 22.

12. Fridiana, D. (20I2). UJI ANTIINFLAMASI EKSTRAK UMBI RUMPUT TEKI (Cyperus rotundus L) PADA KAKI TIKUS WISTAR JANTAN YANG DIINDUKSI KARAGEN. Universitas Jember.

13. Noval, N., \& Raihana, R. (20|9). Efek Ekstrak Etanol Akar Pasak Bumi (Eurycoma Longifolia, lack) terhadap Ekspresi HRAS pada Organ Hati Tikus Galur Sprague Dawley pada Pemberian Doxorubicin. Jurnal Surya Medika (JSM), 5(I), II 5 130.

14. Barbosa Filho, J., Piuvezam, M., Moura, M., Silva, M., Lima, K., da-Cunha, E., Fechine, I., \& Takemura, O. (2006). Anti-inflammatory activity of alkaloids: A twenty-century review. Revista Brasileira De Farmacognosia-Brazilian Journal of Pharmacognosy - REV BRAS FARMACOGN, 16. https://doi.org/10.1590/SO102$\underline{695 \times 2006000100020}$

15. Patel, S. S., Savjani Assistant Professor, J. K., Patel, S. S., \& Savjani, J. K. (20I5). Systematic review of plant steroids as potential anti- inflammatory agents: Current status and future perspectives. The Journal of Phytopharmacology JPHYTO, 4(42), |2|-125. www.phytopharmajournal.com 